\title{
THE EFFECT OF POTASSIUM BROMATE ON SOME HAEMATOLOGICAL PARAMETERS OF WISTAR RATS
}

\author{
P. U. ACHUKWU, S. A. UFELLE, E. O. UKAEJIOFO, F. E. EJEZIE ${ }^{1}$, D. N. \\ NWACHUKWU ${ }^{2}$, U. I. NWAGHA ${ }^{2}$, W. C. NWORIE ${ }^{3}$, U. S. B. ANYAEHIE ${ }^{2}$ \\ Department of medical laboratory sciences, faculty of health sciences and technology, college of medicine, \\ university of Nigeria, Enugu campus. Nigeria, 1 Department of Medical Biochemistry, College of Medicine, \\ University of Nigeria Enugu Campus. Nigeria. 2 Department of Physiology, College of Medicine, University of \\ Nigeria Enugu Campus. 3 Department of Haematology, Neuropsychiatric Hospital Enugu, Nigeria.
}

\begin{abstract}
Summary: Potassium bromate used widely in foods has been associated with various complications in humans. However there is paucity of literature on adverse effects on haematological parameters. Thus we decided to carry out an experimental study to determine the effects of potassium bromate on some blood indices using Wister rats. Twenty (20) male Wister rats aged 2-3 months obtained from the department of Veterinary Medicine, University of Nigeria Nsukka were acclimatized for two weeks. They were divided into five groups and fed with graded doses of potassium bromate solution for six weeks. One of the groups served as the control. Pre and post administration blood samples were collected and analyzed the same day using standard methods. The results revealed significant decrease in the platelet count when compared with the controls $(\mathrm{P}<0.05)$. There were no statistically significant differences in the mean Cell haemoglobin concentration, haematocrit, and total leukocyte counts between the test and control rats. Potassium bromate is injurious to health if consumed continuously and in high quantity. It has been shown to reduce platelet count in rats, and thus may cause thrombocytopenia in humans .It is therefore imperative to take adequate measures to eliminate the use of potassium bromate in the preparation of food products

Key words: Potassium bromate, blood count, reduced platelet count.
\end{abstract}

\section{Introduction}

Potassium bromate is a white crystal, granules or powder, which is colourless, odourless, and tasteless. It has no medicinal value but is added to flour as a maturing agent, to dough, to fish paste as a conditioner, and also to beer or cheese (Chipman 1988). It has also been used as a constituent in cold wave hair solution (Ueno 2000).

Potassium bromate is a substance that has a vapour density of 5.8 (air=1) and density of 3.27 $\left(\mathrm{gcm}^{3}\right)$ and when in contact with combustible material may cause fire. It is incompatible with organics, reducing agents, aluminum, and finely powdered metals (USEPA 1993). When heated, it produces toxic fumes of bromine (RCC 1999).It has an infinite solubility in water, and at drinking water $\mathrm{pH}$, it should exist almost exclusively in the ionic form (USEPA 1998a). The problem of potassium bromate started with ozonation of drinking water to form bromate as a major by product (WHO (1993). When research was done to confirm the safety of ozonated water, it was found that potassium bromate causes renal cancer in rats when they drank water with potassium bromate.Following this discoveries, many countries, Health Organizations and Agencies started banning the use of potassium bromate (NAFDAC ,2003). Some of the countries where potassium bromate has been banned include United Kingdom in 1990 and Canada in 1994. Other countries where potassium bromate has been removed from the list of permitted food additives are Belgium, Greece, Norway, Denmark, Spain, Portugal, Japan, and Switzerland (NAFDAC 2003). WHO also banned the use of potassium bromate in 1993. In Nigeria, the National Agency for Food and Drug Administration and Control in 2002, held consultative meeting with the Association of Master Bakers in the various states of the country on the danger of use of potassium bromate in bread and the need to stop its use. Despite the awareness created by NAFDAC on the danger of using potassium bromate as flour enhancer, many bakers still use the restricted substance (NAFDAC 2003).In Nigeria, there is no technology yet to detect food product containing potassium bromate or the dangerous health hazard that potassium bromate may cause. However several researches have been carried out in different parts of the world to prove that potassium bromate is dangerous to health if consumed in food or water. It has been shown to be nephrotoxic in both man and experimental animals (Uchida et al 2006).Furthermore it induces renal cell tumors, mesotheliomas of the peritoneum, and follicular cell tumors of the thyroid (Kurokawa et al. 1990).

It was discovered that potassium bromate which was administered to male rats in drinking water resulted in combined incidence of adenomas and carcinoma of the kidney (Kurokawa et al .1986). Mice appeared to be more sensitive than 
P. U. Achukwu et al

rats to the effect of potassium bromate exposure (Kurokawa et al. 1986). At the kidney, the potassium bromate induces renal oxidative stress which is known to cause renal failure, methaemoglobinaemia and kidney cancer (De Angelo et al 1988, Parsons and Chipman 2000). There has not been much reports on the effect of potassium bromate on haematological indices, thus this research was designed to experimentally investigate the effect of potassium bromate on some blood parameters using Wister rats.

\section{Materials and Method}

Twenty Wister rats collected from Veterinary medicine department of University of Nigeria were divided into five groups of four rats each. The first four cages labeled (A-D) were administered with graded doses of potassium bromate solution in the order of $30 \mathrm{mg} / \mathrm{kg}, \quad 50 \mathrm{mg} / \mathrm{kg}, \quad 70 \mathrm{mg} / \mathrm{kg}$, and $90 \mathrm{mg} / \mathrm{kg}$ body weight respectively for six weeks. The fifth cage labeled (E) served as the control and was administered with water only.Pre and post administration of potassium bromate blood samples were collected into EDTA anti-coagulant containers from twenty male albino Wister rats aged 2-3 months. QBC Auto read Plus centrifugal system made by Becton Dickson was used for auto analysis of venous blood collected into EDTA containers. We measured the following parameters; total leucocyte count, haematocrit and mean cell haemoglobin concentration. The blood film was read using standard methods (Davies and Lewis 2007).

Statistical analysis. The results of the tests were statistically analyzed using SPSS windows version 11 software. Results were presented as mean and standard deviation. Student t-test was used to test for significance. $\mathrm{P}$ values of $\leq 0.05$ at $95 \%$ confidence interval were considered as significant.

\section{Results}

There was a non significant increase in total white cell count as shown in Table 1. The changes in the Mean Cell Haemoglobin Concentration and Haematocrit were also not statistically significant $(\mathrm{P}>0.05)$. The results are as shown in Tables, 2, and 3 respectively. The post administration results of Platelet count showed a significantly decreased value when compared with both the pre administration and the control result $(\mathrm{P}<0.05)$. The blood film for pre administration blood samples for test and control shows normocytic/normochromic red blood cells, leucocytes and platelet appeared normal. The blood film for post administration blood samples for test shows normocytic/normochromic red blood cells, platelets appeared inadequate. There was with moderate lymphocytosis.

\section{Discussion}

From this study, it was observed that leucocytes and platelet counts were decreased in rats administered with potassium bromate in water. The decrease in the leucocyte count though not statistically significant is in agreement with the work of Thompson and Westfall (1949), who reported a decrease of leucocytes count from $15,500 / \mathrm{mm}^{3}$ to $9,600 / \mathrm{mm}^{3}$ in a two and half year old boy in a period of two months after swallowing a half glass of neutralizer containing potassium bromate. Decreased leucocyte count has also been reported due to consumption of chemicals like Bromate (Hoffbrand et al. 2004).

Table 1: Mean Total Leukocyte Count $\left(\times 10^{9} / \mathrm{L}\right) \pm$ SD

\begin{tabular}{llll}
\hline Group & $\begin{array}{l}\text { Pre- } \\
\text { Administration }\end{array}$ & $\begin{array}{l}\text { Post } \\
\text { Administration }\end{array}$ & P-Values \\
\hline A & $12.3 \pm 0.30$ & $12.0 \pm 0.41$ & $\mathrm{P}>0.05$ \\
$\mathrm{~B}$ & $10.9 \pm 0.25$ & $9.5 \pm 0.93$ & $\mathrm{P}>0.05$ \\
$\mathrm{C}$ & $11.0 \pm 0.30$ & $10.4 \pm 0.61$ & $\mathrm{P}>0.05$ \\
$\mathrm{D}$ & $12.7 \pm 0.30$ & $10.0 \pm 0.58$ & $\mathrm{P}>0.05$ \\
& & & \\
E & $11.3 \pm 0.62$ & $11.5 \pm 0.44$ & $\mathrm{P}>0.05$ \\
(Control) & & & \\
\hline
\end{tabular}

Table 2: Mean Haematocrit Values (\%) \pm SD

\begin{tabular}{llcc}
\hline Group & $\begin{array}{c}\text { Pre- } \\
\text { Administration }\end{array}$ & $\begin{array}{c}\text { Post } \\
\text { Administration }\end{array}$ & $\begin{array}{c}P- \\
\text { Values }\end{array}$ \\
\hline $\mathrm{A}$ & $35 \pm 1.80$ & $48 \pm 1.87$ & $\mathrm{P}<0.05$ \\
$\mathrm{~B}$ & $39 \pm 0.39$ & $43 \pm 1.87$ & $\mathrm{P}>0.05$ \\
$\mathrm{C}$ & $40 \pm 1.87$ & $39 \pm 1.22$ & $\mathrm{P}>0.05$ \\
$\mathrm{D}$ & $39.5 \pm 1.87$ & $35 \pm 1.41$ & $\mathrm{P}>0.05$ \\
$\mathrm{E}$ & $37.2 \pm 2.2$ & $40.5 \pm 0.61$ & $\mathrm{P}>0.05$ \\
(Control) & & & \\
\hline
\end{tabular}

Table 3: Mean Cell Haemoglobin Concentration (MCHC) Values (\%) \pm SD

\begin{tabular}{llll}
\hline Group & $\begin{array}{l}\text { Pre- } \\
\text { Administration }\end{array}$ & $\begin{array}{l}\text { Post } \\
\text { Administration }\end{array}$ & $\begin{array}{l}P \text { - } \\
\text { Values }\end{array}$ \\
\hline $\mathrm{A}$ & $33.4 \pm 1.30$ & $33.8 \pm 0.78$ & $\mathrm{P}>0.05$ \\
$\mathrm{~B}$ & $33.0 \pm 1.41$ & $33.7 \pm 0.15$ & $\mathrm{P}>0.05$ \\
$\mathrm{C}$ & $33.0 \pm 1.00$ & $33.3 \pm 0.18$ & $\mathrm{P}>0.05$ \\
$\mathrm{D}$ & $33.2 \pm 0.61$ & $32.8 \pm 0.12$ & $\mathrm{P}>0.05$ \\
$\mathrm{E}$ & $33.6 \pm 0.74$ & $33.3 \pm 0.30$ & $\mathrm{P}>0.05$ \\
(Control) & & & \\
\hline
\end{tabular}

Table 4; Mean Platelet Count (x109/L) + SD

\begin{tabular}{llll}
\hline Group & $\begin{array}{l}\text { Pre- } \\
\text { Administration }\end{array}$ & $\begin{array}{l}\text { Post } \\
\text { Administration }\end{array}$ & $\begin{array}{l}P \text { - } \\
\text { Values }\end{array}$ \\
\hline A & $353 \pm 15.30$ & $150 \pm 11.37$ & $\mathrm{P}<0.05$ \\
$\mathrm{~B}$ & $242 \pm 4.63$ & $120 \pm 3.74$ & $\mathrm{P}<0.05$ \\
$\mathrm{C}$ & $313 \pm 17.16$ & $170 \pm 6.16$ & $\mathrm{P}<0.05$ \\
$\mathrm{D}$ & $336 \pm 11.57$ & $190 \pm 3.08$ & $\mathrm{P}<0.05$ \\
$\mathrm{E}$ & $350 \pm 16.20$ & $300 \pm 9.35$ & $\mathrm{P}>0.05$ \\
(Control) & & & \\
\hline
\end{tabular}


The platelet count showed statistically significant decreased values in post administration rats when compared with the control. These reductions in the leucocyte and platelet count could be due to the DNA strand breakage in these cells induced by the oxidative stress associated with potassium bromate, (Chipman et al. 1988, Sai et al .2000, Parson and Chipman, 2000, Thompson and Westfall 1949).Furthermore, there could have been bone marrow suppression with selective megakaryocyte depression (Hoffbrand et al. 2004). On the other hand it could be that potassium bromate has a direct damaging effect on the platelets. The blood picture showed moderate lymphocytosis in rats administered with potassium bromate, which could be due to the depletion of the intra cellular GSH by diethylmaleate in lymphocytes, which decreases the amount of strand breakage induced by potassium bromate (Parson and Chipman, 2000). There was no statistically significant difference in the test and control samples of the MCHC and haematocrit values. In the report of a two and half year boy who swallowed a neutralizing solution containing potassium bromate, the only haematological finding was a change in hemoglobin concentration from $11.4 \mathrm{~g} / \mathrm{dl}$ to $10.7 \mathrm{~g} / \mathrm{dl}$ in a period of two months (Thompson and Westfall 1949). Furthermore, a study in mice showed no change in blood parameters apart from transient reduction in red cell count (Ginocchio et al, 1979)

Potassium bromate (KBrO3) has many dangerous effects. It exerts nephrotoxic and ototoxic effects in experimental animals as well as in man. $\mathrm{KBrO} 3$ is a carcinogen inducing renal cell tumors, mesotheliomas and thyroid follicular cell tumors in rats. It is highly probable that active oxygen radicals are involved in these effects leading to DNA damage. We have also noted its possible toxic effects on platelets. Further studies should be encouraged in this regard. Furthermore; the effort to stop the use of potassium bromate in preparation of foods should be intensified. NAFDAC should also focus attention not only on bread, but on other bakery products in which flour is used as a raw material. The physical properties of $\mathrm{KBrO} 3$ make it easy to be taken or administered as a poison to human, thus its use and handling should be highly regulated by the relevant authorities.

\section{References}

Chipman, J.K., Davies, J.E., Parson, J.L., O'Neill, G., and Fawell., J.K. (1988): DNA Oxidation by Potassium Bromate; a Direct Mechanism or Link to Lipid Peroxidation? Toxicology. 126:93-102.
De Angelo, A.B., George, M.H., Kilburn, S.R., Moore, T.M. and Wolf, D.C. (1988). Carcinogenicity of Potassium Bromate Administered in the Drinking Water of Male B6C3F Mice and F344/N Rats. Toxicol. Pathol. 26:587-594.

Hoffbrand, A.V., Petit, J.E. and Moss P.A.H.(2004). Essential Haematology. $\left(4^{\text {th }}\right.$ edn) Blackwell, Oxford. pp 252-253.

Kurokawa, Y., Aoki, S., Matsushinna, Y., Takamura, N., Imazawa, T. and Hayeshi, Y. (1986a). Dose Response Studies on the Carcinogenicity of Potassium Bromate in F344 Rats after long term Oral Administration. J. Natl. Cancer Inst. 77: 977-982.

Kurokawa, Y., Maekawa, A., Takahashi and M. ,Hayasi, Y. (1990).Toxicity and Carcinogenicity of Potassium Bromate; A New Renal Carcinogen. Environ. Health Persp. 87:309-335.

Ginocchio, A.V., Waite, V., Hardy, J., Fisher, N., Hutchinson, J.B. and Berry, R. (1979). Long-term toxicity and carcinogenicity studies of the bread improver potassium bromate. 2. Studies in mice. Food Cosmet Toxicol, 17, 41-47.

Lewis, S.M.,Bain, B.J. and Bates, I. (eds) (2007).In; Davies and Lewis Practical Haematology, Churchill Livingstone, Edinburgh, United Kingdom. 10 Edition, pp 25-58.

NAFDAC (2003): Consumer Safety Bulletin Volume 2 No. ISSN: 1576-3594.

Parsons, J.L. and Chipman, J.K.(2000).The role of glutathione in DNA damage by potassium bromate in vitro. Mutagenesis.15(4):311-316.

Ricca Chemical Company (RCC). (1999). Material Safety Data Sheet. Section 1: Chemical Product and Company Identification.

Sai, K., Uchiyama, S., Ohno,Y., Hasegawa, R and Kurokawa, Y. (1992).Generation of active oxygen species in Vitro by the interaction of Potassium Bromate with rat kidney. Cell Carcinogenesis 13:333-339.

Thompson, H.C. and Westfall, S.W. (1949). Potassium Bromate Poisoning. Report of a case due to ingestion of a Cold Wave Neutralizer. J. Paed, 34:362-364.

Uchida, H. A., Sugiyama, H., Kanehisa, S., Harada, K., Fujiwara, K. and Ono, T.(2006). An elderly patient with severe acute renal failure due to sodium bromate intoxication. Intern Med 45: 151-154.

Ueno, H., Oishi, K., Sayato, Y. and Nakamuro, K. (2000). Oxidative cell damage in kat-sod anay of oxyhalides as inorganic disinfection by products and their occurrence by ozonation. Arch Environ. Contam. Toxicol. 38:1-6.

USEPA (1993): Final Draft for the Drinking Water Criteria Document on Bromate. Prepared for the Health and Ecological Criteria Division, Office of Science and Technology, Office of Water by Clement International Corporation.

USEPA (1998a). National Primary Drinking Water Regulation: Disinfectants and Disinfection Byproducts: Final Rule Federal Register 63 (241): 69389-69476.

WHO (1993). Guidelines for Drinking Water Quality, $2^{\text {nd }}$ Edition volume 1. Recommendations Geneva, WHO, P.96. 